\title{
Utilization of Egyptian Ilmenite Ore for Steel Surface Preparation in Petroleum Field
}

\author{
Mahmoud Ibrahim Abdou ${ }^{1}$, Mohamed Abd EL-Fattah Moustafa ${ }^{{ }^{*} \text {, }}$ \\ Hany El-Sayed Ahmed ${ }^{1}$, Hamada Abd El-Wahab ${ }^{2}$ \\ ${ }^{1}$ Production Department, Egyptian Petroleum Research Institute (EPRI), Cairo, Egypt \\ ${ }^{2}$ Chemistry Department, Faculty of Science, Al Azhar University, Cairo, Egypt \\ E-mail: \{*eprimaf68, Mahmoud_ibrahim_abdu, esmail_hany\}@yahoo.com,hamada19982000@hotmail.com \\ Received December 6, 2010; revised June 9, 2011; accepted June 20, 2011
}

\begin{abstract}
The construction of gas and oil plants include many items such as steel structures, equipments, piping, tanks and vessels at different conditions such as offshore, onshore, above and underground shall be protected against corrosion by coating. The protective value of a coating system is proportional to the surface preparation; the objectives of the surface preparation are the surface cleanliness and the surface profile of the substrate. The surface preparation is usually achieved by blast cleaning using different types of abrasive. Due to its high hardness and low cost, silica sand has been used extensively for impact abrasion. It is, however, very brittle with most grain disintegrating on impact, causing excessive levels of siliceous dust which is a major health hazard and causes serious environmental pollution. Consequently, it has been banned as impact abrasive material in most countries around the world. Considerable research has been done in the last twenty years to find an impact abrasive material as hard as silica and that respects. So it was important to search for sand substitution among the local abundant minerals in Egypt. Waste product obtained from ilmenite ore extracted from the mine was found to be the most suitable alternative abrasive. This work shows the abrasive types, the occurrence of the ilmenite ore. The chemical properties, physical properties and microscopic examination of the waste were investigated. The obtained result indicates that, the waste product obtained from ilmenite ore can be utilized for abrasion as sand substitution.
\end{abstract}

Keywords: Blast Cleaning Material, Ilmenite, Abrasive Material, Surface Cleanliness, Surface Profile and Surface Preparation.

\section{Introduction}

Blast cleaning is a tried and tested method of cleaning metal surface and preparing them for coating or for such sophisticated modern finishing process are necessary to resist corrosion in the atmosphere, under water or in the aggressive environments. Although the process has in use for a long time and the earliest sand blasting operations can be dated back to the middle of the last century. Blast cleaning is certainly not limited to the realms of intermediate technology [1]. The protective value of a coating system is proportional to the cleanliness of the surface of the substrate to which the coating system is applied. Experience from practice has established that some $85 \%$ off all coating failure can be traced back to insufficient surface preparation [2]. The objectives of surface preparation are:

\subsection{Surface Cleanliness}

Surface cleanliness is used to remove from the surface any substance detrimental to the performance of coatings. The enemies of coating performance are especially mill scale, rust, soluble salts, dust, oil and grease. The cleanliness of steel surface is judged in comparison with agreed standard. At present, there are four series of standard in common usage, Svensk Standard SIS 055900 -1967 (Swedish Standard), BS (British Standard), the third is a combination of both: BS 7079 (ISO 8501-1) 1988 and the fourth is the American Standard-SSPC (Steel Structures Painting Council) Series in addition to National Association Corrosion Engineering (NACE) 
standard. The standard equivalents are illustrated in Table 1.

\subsubsection{Swedish Standard}

Applies to steel which being prepared by blast cleaning or mechanical methods (scraping and wire brushing). The standard provides both a description and appropriate photograph of the surface condition of the steel prior to any surface preparation and after surface preparation. It should be noted that the Swedish Standard makes no mention of surface profile.

\subsubsection{British Standard (BS)}

Refers only to the condition of the steel surface after grit blasting, The standard provides a detailed description of the level of surface cleanliness; in addition the standard makes the reference to surface roughness (profile) and the use a British Standard of abrasive.

\subsubsection{ISO (8501-1)1988}

This document is now in common use since it is an International Organization Standard and in corporate the pictorial standards from Swedish Standard SIS 055900 -1967. The ISO standard gives pictorial standards for surface preparation using different type of abrasives and for flame cleaning. Where new steel work is being prepared for painting, the steel surface should be classified of rust grade $\mathrm{A}, \mathrm{B}, \mathrm{C}$ or D [3].

\subsection{Surface Profile}

To create a profile "an anchor pattern" of the substrate for specific coating system to be applied. The surface profile influences the performance-especially the adhesion of the applied coating. The profile may be defined as the greatest vertical distance between the summit of any peak on a blast-cleaned surface and the bottom of an immediately adjacent trough. Recommended profile, often called the amplitude of 100 microns, although generally smaller amplitudes are devisable depending on coating system type and thickness to be applied [4].

\section{Abrasives}

The abrasive giving the required profile and the greatest efficiency should be chosen, abrasive come in many

Table 1. The standard equivalents for surface cleanliness.

\begin{tabular}{ccccccc}
\hline Standard & BS & Swedish & SSPC & ISO 8501 & NACE \\
\hline & First Quality & Sa 3 & White Metal & Sa 3 & Grade 1 \\
Scale & Second Quality & Sa 2 & $1 / 2$ & Near-White & Sa 2 1/2 & Grade 2 \\
& Third Quality & Sa 2 & Commercial & Sa 2 & Grade 3 \\
\hline
\end{tabular}

forms and can be classified in several different ways as 1) non metallic (mineral) expendable such as copper slag, nickel slag, glass bead sand and garnet, 2) metallic (recyclable) such as angular chilled iron (ACI), steel grit, steel shot and mix of shot and grit and 3 ) agriculture by product such as coconut shell, eggshell and corn husk. There are two type of aggregate, coarse aggregate which predominantly retained on the $4.75 \mathrm{~mm}$ sieve and fine aggregate which passing the $9.5 \mathrm{~mm}$ sieve and almost entirely passing the $4.75 \mathrm{~mm}$ sieve and predominantly retained on the 75 microns sieve [5]. A method of removing a coating, such as paint, varnish, biological growth or grime, from a surface, the method comprising selecting a suitable particulate solid having a particular size of from $150-250 \mathrm{~mm}$ and fluid carrier to form a spray mixture and spraying the mixture as a jet spray so as to impact and at least partially remove the coating. The hardness of the particulate solid is preferably less than 8.0 on the Moh scale. It is particularly preferable for hardness to be 6.0 to 7.0 on the Moh scale. For example, grit or sand-blasting has been used for many years to clean stone building, painted metals surfaces such as railings and superstructures including oil rig [6], the particles of grit or sand are mobilized by means of a carrier fluid, normally air (dry blasting) or water (wet blasting). Mineral slags characterized by high hardness such as those contain copper, nickel, iron [7] and alloys [8] have been used. These slags are quenched from molten state with cold water and crushed and/or grinded, giving each particle a glassy brittle structure with distinct fracture lines. Upon blasting impact, the slag particle shatters into minute particles and become airborne due to their small size and low specific gravity, resulting in the generation of high dust levels. Moreover, these slags, especially the copper slag and nickel slag, are waste products of the metals refining industry and frequently contain unacceptable levels of toxic heavy metals such as lead, copper, zinc, arsenic and cadmium, etc. Finally, slag crushing and/or grinding are energetically inefficient processes which increase the cost of impact abrasive materials. There therefore exists a need for a new impact abrasive material for blast cleaning which respects the governmental norms for dust emissions and is cost efficient. Ferrous-nickel slag is widely used in open dry blast cleaning operations in Greek shipyards thus annually generating thousands of tons of blast cleaning waste [9]. To overcome the problem mentioned previously ilmenite tailing particles have been used as abrasive material for blast cleaning; the maximum efficiency is reached for particles between 10 mesh and 250 mesh $(1.68 \mathrm{~mm}$ and $68 \mu \mathrm{m})$. The bigger particles are efficient to clean objects covered with a thick or highly adhesive layer of oxides while the finer ones are efficient to clean objects that are 
covered with a thin or new layer of oxides [10]. Ilmenite tailing particles are a waste product obtained in beneficent plant of an ilmenite ore metallurgical complex. The particles are preferably washed, dried and screened before being used as impact abrasive material they are separated in particle-size range to improve their efficiency for blast cleaning. Ilmenite is named for its place of discovery at Ilmen Lake in the Ilmen Mountains, Miask in the southern portion of the Ural Mountains of Russia. Ilmenite, hematite and corundum all have similar structures and belong to a more or less informal group called the hematite group, but ilmenite has a different crystal form and is not as strongly magnetic. Ilmenite lends it name to a group of similar called ilmenit group, a subgroup of the hematite group of minerals. The general formula for the group is $\mathrm{ATiO}_{3}$; where A can be iron, magnesium, zinc and/or manganese. Australia was the world's largest producer and exporter of ilmenite ore in 2005-2006, with 1.1 million tones, followed by South Africa, Canada, China and Norway [11].

\subsection{Occurrence and Characteristics of the Egyptian Ilmenite}

The deposits of ilmenite ore occurs in Wadi Abu Ghalaga in the South part of the Eastern Desert, the area comprises the eastern portion of Hamata sheet, $30 \mathrm{~km}$ of Red Sea and $100 \mathrm{~km}$ South Marsa Alam, The deposits of Wadi Abu Ghalaga included two main parts, the eastern part consists of metavolcanics and the western part composed of ilmenite deposit surrounded by gabbroic rocks and these in turn are bordered from the western and southeastern sides by a biotite gneissose granite [12]. The only mention in the literature that the ilmenite ore is not purely magnetic is that given by El-Shazly, [13] who suggested that the ilmenite was deposited in two stages as 1) Ilmenite grains were first formed during solidification of the gabbro magma and 2) The ilmenite grains were later segregated by later metamorphism and metamorphic differentiation to from a deeply inclined ore body. The mode of origin though sounds in principle and in good accordance with the present findings, yet there are certain substantial differences between the two theories. Basta and Takla [14] consider the ore deposit itself as having been formed in the magmatic phase and that the metamorphic phase only resulted the mobilization and recrystallization of the ore minerals and the transformation of the ilmenite magnetite intergrowths into hemo-ilmenite. Kraus [15] considers the deposition of Abu Ghalaga ore as based on crystallization differentiation followed by an inferior hydrothermal phase. He suggested that in the deposit both the ilmenite and primary silicates were crystallized simultaneously. Basta and Takla [16] described the mineralogy of ilmenite as 1) Homogeneous ilmenite free of any exsolution lamellae is mainly present in the gabbroic rocks where it constitutes the principal type of ilmenite. It occur either as granular aggregate with titaniferous magnetite or occasionally as separate discrete grains which are entirely surrounded by silicates. It is usually grey with dark reddish brown tint, being very poor in $\mathrm{Mg}$ and $\mathrm{Mn}, 2$ ) the ferri-ilmenite, of the hematite-ilmenite exsolution intergrowths, is usually paler in color and of higher reflectivity than the homogeneous ilmenite. In the typical cases, they form rows of spindle-shaped or bladed lamellae but in other cases, they may be rounded, oval rectilinear or irregular blebs. Ilmenite is composed mainly of titanium oxide $\left(\mathrm{TiO}_{2}\right)$, silica $\left(\mathrm{SiO}_{2}\right)$ and therefore considered a low grade titanium ore. The ore body is mainly composed of ilmenite, varying from $70.2 \%-97.9 \%$ Ikonnicova [17], with minor amounts of pyroxene amphibole, biotite and sphene. Accordingly, this paper investigates the Egyptian ilmenite ore to be used as expendable abrasive materials for steel surface preparation in the petroleum field.

\section{Experimental}

The experimental work divided into two phases.

\subsection{Field Tests}

\subsubsection{Blast Cleaning}

Blast cleaning is the common multiple for all the methods where abrasives of different kinds are propelled by means of compressed air onto a surface, the main pats are: compressor, pressure pot contains the abrasive, air hoses, abrasive hoses/nozzles. Moisture and oil separator and deadmans handle, environmental conditions should be measured prior to starting blasting such as ambient temperature, steel temperature, relative humidity and dew point. Blast cleaning operation shall not be carried out when the steel surface temperature is less than $3^{\circ} \mathrm{C}$ above the dew point or when the relative humidity of the air exceeds $85 \%$ [18].

\subsubsection{Assessment of Dust Surfaces Prepared for Coating}

The presence of dust on the surface prepared for coating can be detected as follow 1) cut a piece about $200 \mathrm{~mm}$ long, press about $150 \mathrm{~mm}$ on the surface under test, 2) place the thumb across one end of the tape and move the thumb, remove the tape from the test surface and place in on an appropriate display board, 3) assess the quantity of dust on the tape by comparing it visually with equivalent references and assess the predominating dust particle size on the adhesive tape by reference standard which desig- 
nated from 0 to 5 [19].

\subsubsection{Surface Cleanliness}

Visual cleanliness of the steel before and after surface preparation, examine the steel surface and compare it with standard photographs as per ISO 8501-1.

\subsubsection{Surface Profile}

Surface profile gauge, testex press- $\mathrm{O}$ - film tape and comparator gauge are the instruments provide a quick and effective method of ascertaining the grading of surface profile [20].

\subsubsection{Salt Contamination}

Soluble salts on the surface are taken into solution by placing high purity sample paper, eject $1.6 \mathrm{~mm}$ of water onto its surface, place wetted paper on the area to be sampled, pressing it then place the sample paper over the concentric copper electrode a reading will be displayed $\mu \mathrm{g} / \mathrm{cm}^{2}$. This being undertaken using a model elcometer 130 SCM 400 salt contamination meter.

\subsection{Laboratory Tests}

\subsubsection{Chemical Analysis}

In this research work chemical analysis was carried out to check the chemical composition of ilmenite ore and the presence of corrosion constituents and adhesionimpairing contaminants.

\subsubsection{Sieve Analysis}

Dry the sample to the constant mass at temperature of $110^{\circ} \mathrm{C} \pm 5^{\circ} \mathrm{C}$ split the sample into two or more portions the size of the test sample after drying shall be $300 \mathrm{~g}$ minimum, hold the individual sieve provided with fitting pan and cover, use a mechanical sieve shaker, continue sieving for a sufficient period, after completion calculate the percentages passing [21].

\subsubsection{Specific Gravity}

Dry the sample to the constant mass at temperature of $110^{\circ} \mathrm{C} \pm 5^{\circ} \mathrm{C}$ cool in air at room temperature for 1 to $3 \mathrm{~h}$; subsequently immerse the aggregate in water at room temperature for a period of $24 \pm 4$ hours [22]. Specific gravity can be calculated as follow: Sp. Gravity $=(B-A) /$ (D-A) $-(\mathrm{C}-\mathrm{B}) * \rho$ where A, B, C, D and $\rho$ is the weight of empty Pycnometer, weight of empty Pycnometer + Aggregate, weight of empty Pycnometer + Aggregate + water, Weight of empty Pycnometer + water and water density respectively.

\subsubsection{Bulk Density}

Bulk density of aggregate defined as the mass of a unit volume of bulk aggregate material, in which the volume includes the volume of voids between particles expressed in $\mathrm{kg} / \mathrm{m}^{3}$. This test method applicable to aggregate not is exceeding 5 in. (125 mm) in nominal maximum size [23]. Bulk density calculation is as follow: $\mathrm{M}=(\mathrm{G}-\mathrm{T}) / \mathrm{V}$ where $M, G, T, V$ is bulk density of aggregates $\left(\mathrm{kg} / \mathrm{m}^{3}\right)$, mass of the aggregate plus the measure $(\mathrm{kg})$, mass of the measure $(\mathrm{kg})$ and volume of the measure $\left(1 / \mathrm{m}^{3}\right)$ respectively.

\subsubsection{Conductivity}

Weigh a test portion of $(100 \pm 0.1) \mathrm{g}$ of the sample into a $250 \mathrm{ml}$ flask and add $(100 \pm 0.1) \mathrm{ml}$ of the conductivity water of at least grade 2 purity. Shake for $5 \mathrm{~min}$ and allow standing for $1 \mathrm{~h}$. then shaking again for $5 \mathrm{~min}$ and allowing settling. Transfer sufficient of the liquid to fill the conductivity cell of the conductivity-measuring bridge. Measure the conductivity of the solution in millisiemens per meter at $20^{\circ} \mathrm{C}$ [24]. $\gamma \mathrm{s}=\gamma \mathrm{m} \times \mathrm{K} 20$ where $\gamma \mathrm{s}, \gamma \mathrm{m}$ and $\mathrm{K} 20$ is the conductivity in millisiemens per meter of the abrasive, conductivity in millisiemens per meter of the solution at $20^{\circ} \mathrm{C}$ and cell constant respectively.

\subsubsection{Determination of Moisture Content}

Clean and dry a container and weigh it to the nearest 0.1 $\mathrm{g}$, take a sample of at least $30 \mathrm{~g}$ of abrasive particle and place in a container, weigh the contents to the nearest 0.1 g. Place the container and contents in the oven to dry at $105^{\circ} \mathrm{C}-110^{\circ} \mathrm{C}$. The abrasive particle is deemed to be dry when the differences in successive weightings of the cooled sample at intervals of $4 \mathrm{hrs}$. Do not exceed $0.1 \%$ of the original mass. Minimum drying time is usually 16 hrs. Calculate the moisture content of the abrasive particle specimen, $\mathrm{W}$, as a percentage of the dry abrasive particle mass to the nearest $0.1 \%$ from the equation [25]. $\mathrm{W}=\left(\mathrm{m}_{2}-\mathrm{m}_{3}\right) /\left(\mathrm{m}_{3}-\mathrm{m}_{1}\right) \times 100 \%$ where $\mathrm{m}_{1}, \mathrm{~m}_{2}, \mathrm{~m}_{3}, \mathrm{~m}_{2}-$ $m_{3}$ and $m_{3}-m_{1}$ is the mass of the container, the mass of the container and wet abrasive particle, the mass of the container and dry abrasive particle, $m_{2}-m_{3}$ is the mass of moisture and $m_{3}-m_{1}$ the mass of dry abrasive particle (in $\mathrm{g}$ ) respectively.

\subsection{7. $\mathrm{pH}$}

In order to indicate whether a solution is acidic or alkaline, the $\mathrm{pH}$ value of the solution is measured. The $\mathrm{pH}$ value is usually measured within a range from 0 to 14 . Pure water has a $\mathrm{pH}$ value of 7 , which is a neutral solution. If a $\mathrm{pH}$ value of less than 7 is measured, it is an acidic solution. And if more than 7, it is an alkaline solution. The $\mathrm{pH}$ scale is logarithmic; this means that for every single point above or below a $\mathrm{pH}$ value of 7 , the solution will be ten times more concentrated. 


\subsection{Microscopic Examination}

The shape of abrasive particle determines the obtained surface profile after blasting operation so that microscopic examination for different size of ilmenite ore was examined.

\section{Results and Discussion}

\subsection{Chemical Analysis}

Chemical analysis for ilmenite ore indicates that; Ilmenite ore composed mainly of iron and titanium, Ilmenite ore doesn't contain corrosive constituents and adhesionimpairing contaminants as shown in Table 2. In addition silica $\left(\mathrm{SiO}_{2}\right)$ content is very low $9.06 \%$ compared with silica sand and garnet which contain $95 \%$ and $36 \%$ respectively as represented in Figure 1.

\subsection{Chemical Characteristics of Ilmenite Ore}

\subsubsection{Moisture Content}

The moisture content influences the physical properties of a substance such as weight, density, viscosity, refractive index and electrical conductivity. Ilmenite is natural mineral grains that absorb no water but may be wetted on the surface only.

Table 2. Chemical composition of ilmenite ore in weight $\%$.

\begin{tabular}{lc}
\hline \multicolumn{1}{c}{ Element } & Weight $\%$ \\
\hline Silica $\left(\mathrm{SiO}_{2}\right)$ & 9.06 \\
Iron $\left(\mathrm{Fe}_{2} \mathrm{O}_{3}\right)$ & 28.13 \\
Iron $(\mathrm{FeO})$ & 24.33 \\
Titanium $\left(\mathrm{TiO}_{2}\right)$ & 35.42 \\
Alumina $\left(\mathrm{Al}_{2} \mathrm{O}_{3}\right)$ & 01.23 \\
Magnesium $\mathrm{MgO}$ & 00.61 \\
Calcium $\mathrm{CaO}$ & 00.21 \\
$\mathrm{H}_{2} \mathrm{O}$ & 00.18 \\
Loss of Ignition & 00.59 \\
\hline
\end{tabular}

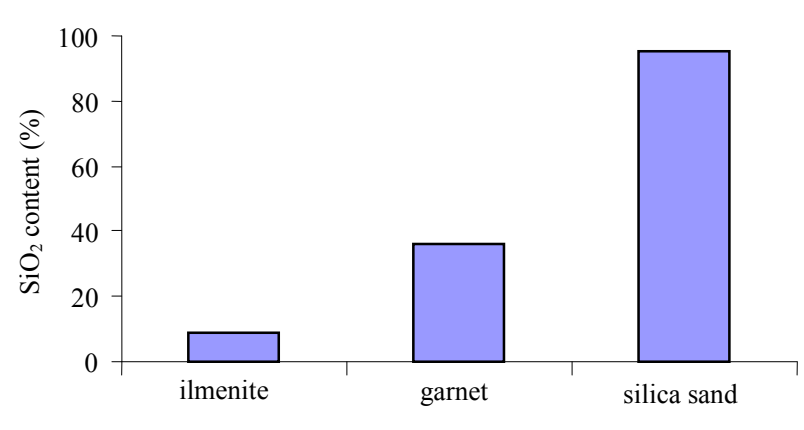

Type of abrasive

Figure 1. Comparison between $\mathrm{SiO}_{2}$ content of different abrasives.

\subsubsection{Conductivity}

The presence of ionic contamination with abrasive can transfer to the steel surface being blasted, where it may accelerate corrosion. Conductivity is useful on establishing the cleanliness of the abrasive at the jobsite. Atypical value of conductivity for a high level of contamination is $500 \mu \mathrm{s} / \mathrm{cm}$. A typical value for a low level of contamination is $150 \mu \mathrm{s} / \mathrm{cm}$. [26].

\subsubsection{Salt Contamination}

The "soluble salts" are formed by the action of sulphate or chloride contaminates with the steel give salts which are almost colorless and will be located at the bottom of corrosion pits. If left under the paint, these substance encourage the passage of water through the paint film, the water then forms more corrosion products thus producing, in time, large volume of rust which will break the adhesion bond between the coatings and the substrate this phenomena is called blistering. So the salt contamination meter used to measure the resistivity of a given sample and convert this value into concentration $\mathrm{mg} / \mathrm{cm}^{2}$ at completion of surface preparation, the amount of water soluble salts on the surface shall not be more than 2 $\mathrm{mg} / \mathrm{cm}^{2}$ [27] and the chloride content should be less than $25 \mathrm{ppm}$.

\subsection{4. $\mathrm{pH}$}

Alkaline substances have $\mathrm{pH}$ values from 7 to 14 , the corrosion attack on metals is often intensified in acidic and alkaline solutions then ilmenite ore is slightly alkaline which doesn't influence in surface coating.

\subsubsection{Chlorides}

The chloride content of the abrasive should be less than 25 ppm [28] which complies with ilmenite ore. The chemical characteristics of Ilmenite ore are summarized as shown in Table 3.

\subsection{Physical Properties of IImenite Ore}

The physical properties play an important role in abrasive chosen, the obtained results is shown in Table 4.

Table 3. The Chemical Characteristics of Ilmenite ore.

\begin{tabular}{clc}
\hline Item & \multicolumn{1}{c}{ Characteristic } & Result \\
\hline 3.2 .1 & Moisture\% & 0.03 \\
3.2 .2 & Conductivity $\mu \mathrm{s} / \mathrm{cm}$ & 74 \\
3.2 .3 & Salt Contamination $\mathrm{mg} / \mathrm{cm}^{2}$ & 0.1 \\
3.2 .4 & PH & 7.25 \\
3.2 .5 & Chlorides & $<25 \mathrm{ppm}$ \\
\hline
\end{tabular}


Table 4. Physical Properties of Ilmenite ore.

\begin{tabular}{lc}
\hline \multicolumn{1}{c}{ Color } & Black \\
\hline Specific Gravity & 4.1 \\
Bulk density $\left(\mathrm{g} / \mathrm{cm}^{3}\right)$ & 2.2 \\
Mohs Scale Hardness & $6.0-6.5$ \\
Luster & Metallic \\
Fracture & Uneven \\
\hline
\end{tabular}

\subsubsection{Specific Gravity and Bulk Density}

High density ilmenite ore affect on abrasive particle scatter and change their shape on impact is practical in field application.

\subsubsection{Hardness}

Abrasive grain hardness influences both surface preparation and the rate of work, breakdown characteristics, the manner in which abrasive particle scatter, and change their shape on impact is practical in application field. Hard abrasive cut deeper and faster than soft or brittle ones. The abrasive used must obviously be harder than the work piece. Ilmenite is characterized by high hardness 6.0 - 6.5 Moh giving a high impact resistance comparatively to $6.5-7.0$ Moh for silica sand moreover, It respects the governmental norms for dust emission since silica is strongly bonded with other compounds of ele- ments such as sodium, aluminum, potassium, magnesium, iodine, and fluorine. Consequently, free silica released is low. Ilmenite is an economically important and interesting mineral.

\subsection{Mechanical Properties of Ilmenite Ore}

In this research work there are three different sizes of ilmenite ore selected to compare between their characteristics as shown in Table 5 and Figure 2.

\subsubsection{Size}

Particle size range improve the efficiency of ilmenite ore for blast cleaning, grain sizes in the range $0.2-1.8 \mathrm{~mm}$ are considered the most advantageous for cleaning structural steel [29]. The particles are preferably washed, dried and screened before being used as impact abrasive material

\subsubsection{Surface Profile and Surface Cleanliness}

As large size ilmenite cut deeper but clean slower than a smaller or fine abrasive, when comparing same amount of ilmenite. Using too fine abrasive, however, will result in the desired anchor pattern not being achieved as shown in Figure 3.

Table 5. Sieve analysis of three different sizes of ilmenite ore.

\begin{tabular}{ccccc}
\hline US Screen Size & Screen Size $(\mathrm{mm})$ & Sample 1 & Sample 2 & Sample 3 \\
\hline 8 & 2.36 & 03 & & \\
10 & 2.0 & 11 & 17 & \\
14 & 1.4 & 24 & 21 & \\
16 & 1.168 & 34 & 36 & \\
20 & 0.883 & 24 & 24 & 44.5 \\
30 & 0.589 & 02 & & 24.5 \\
40 & 0.417 & & & 16 \\
50 & 0.297 & & & 09 \\
70 & 0.208 & & & 03 \\
80 & 0.180 & & 02 & 03 \\
100 & 0.147 & 02 & 100.0 & 100.0 \\
PAN & & 100.0 & & \\
\hline
\end{tabular}

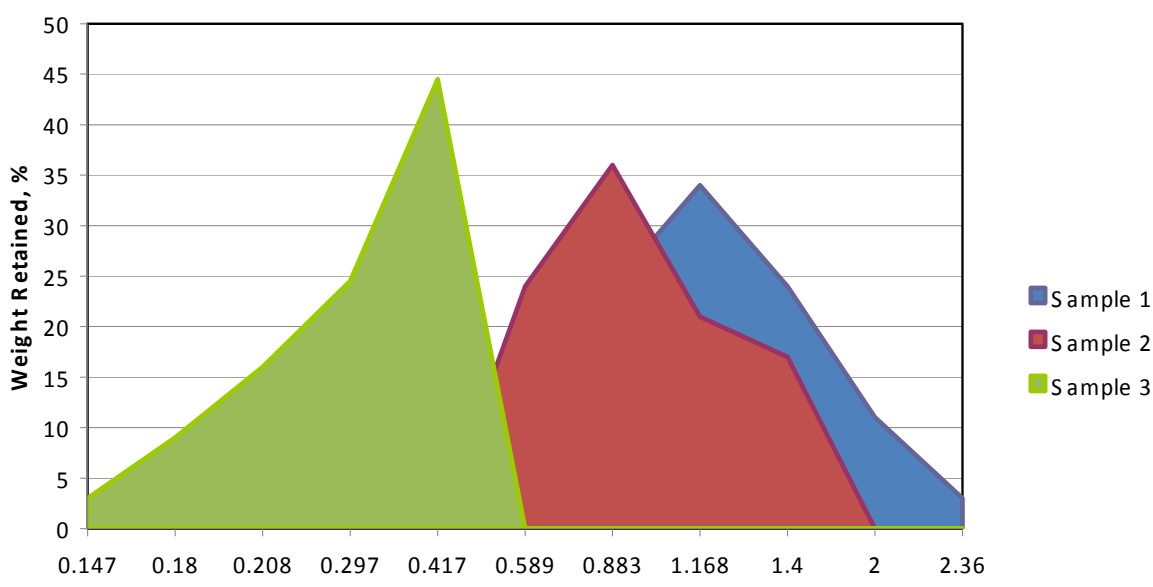

Figure 2. Particle size distribution of three different sizes of ilmenite ore. 


\subsection{Microscopic Examination}

The shape of abrasive particle determines the surface profile. Ilmenite ore contains round, near-spherical as shown in Figure 4. Ilmenite gives a dimpled surface profile while sharp edged provides angular surface profile which is preferred for most coatings.

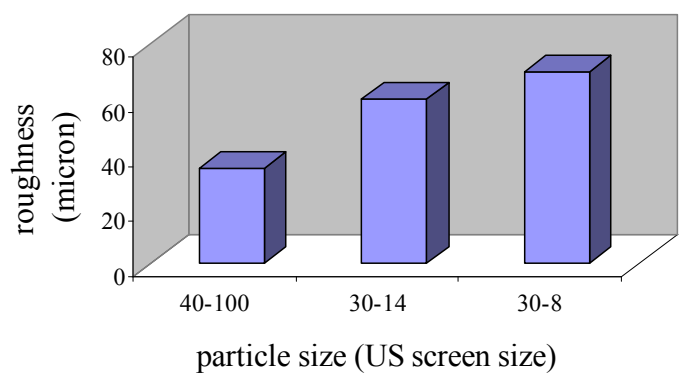

Figure 3. The relation between ilmenite ore particle size and surface roughness.

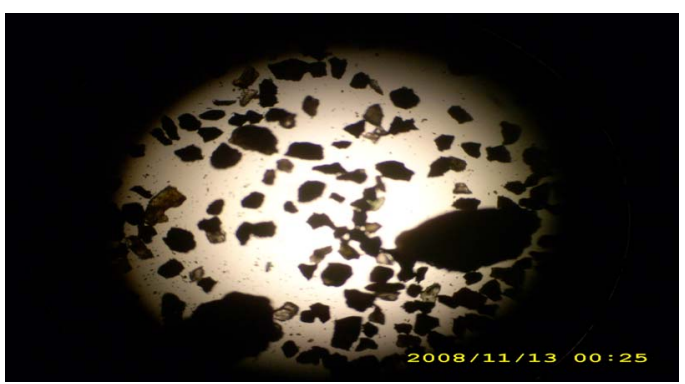

Sample 1

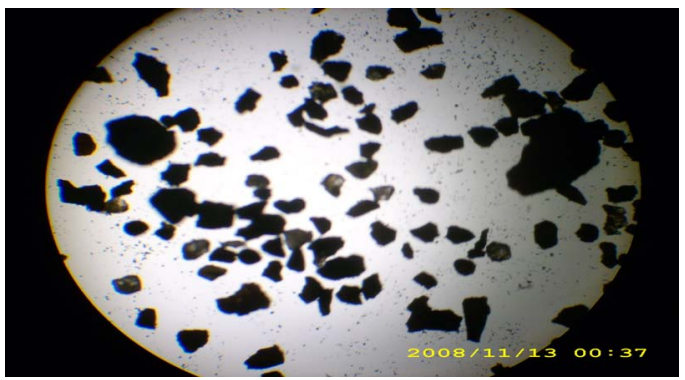

Sample 2

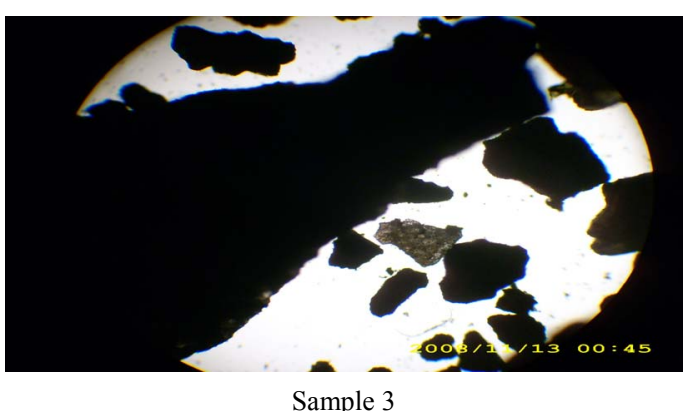

Figure 4. Microscopic examination of three different sizes of ilmenite ore.

\section{Conclusions}

From this study it can be concluded that ilmenite ore can be used as abrasive blasting material for blasting job for the following reasons:

1) Superior surface profile, ilmenite grains are able to reach deep into the cavities of the metal surface and create a uniform profile that is virtually free of embedment and provides an excellent surface for coating adhesion

2) Low dust level, the high density and hardness of ilmenite are the reasons for a low breakdown rate. This ensures significant reduced dust levels, which results in improved operator visibility

3) Non-toxic, ilmenite is chemically inert, non-toxic mineral and contains less than $0.1 \%$ free crystalline silica. Ilmenite doesn't cause any health risk

4) Recyclability, the sub-angular shape, hardness and high density are the reasons for a low break-down and low abrasive consumption. This makes it feasible for recycling without loosing efficiency

5) Cost effective, the low consumption, increased productivity and recyclability result in significant cost saving per square meter blasted

6) Applications, ilmenite is potentially suitable for any blasting application to replace silica sand and slag abrasives. Ilmenite is primarily used for blasting steel substrates and performs well in open blast jobs

7) Variety of ilmenite particle size range as abrasive for blast cleaning meet job needs

8) Comply with international standards and specification, it dose not present specific danger for health and free from corrosive constituents and adhesion-impairing contaminants.

This study proves that beneficiated local waste product obtained in ilmenite ore extracted from the mine can be used as expendable abrasive for cleaning steel surface before anticorrosion coating application in the petroleum field.

\section{References}

[1] R. H. Green, "Blast Cleaning-The Role of the Media." Anti-Corrosion Methods and Materials Journal, Vol. 30 , No. 6, 1983, pp. 4-6. doi:10.1108/eb007222

[2] Hemple Global Supplier of Paint and Coating, "Hemple Protective Coating Manual," May 2004.

[3] Robinson Irwin Technical Support Ltd., "Elcometer Protective Coating Inspection Manual DOC," No. TIME0147, Issue 02, 1994, pp. 5-7.

[4] British Standard Institution (BSI), "Specification for Surface Finish of Blast-Cleaned Steel for Painting," No. 4232, December 1967.

[5] American Society for Testing and Materials, "ASTM Method: C125-07, Standard Terminology Relating to 
Concrete and Concrete Aggregates," 2007.

[6] N. R. Farrow, "Method for Removing Surface Coatings," US Patent No. 6609955, August 26, 2003.

[7] Tomari Masao, Matsuda Minoru and Oshimia Hidetaka "Method and device for treating steel making slag", Japanese Patent No. 590563613, 28 March 1984.

[8] G. L. Smith "Method and Apparatus for Stripping, Cleaning and Treating Surfaces," US Patent No. 4044507, August 1977.

[9] K. Katsikaris, E. Voutsas, K. Magoulas, G. Andronikos and S. Stamataki, "Recycling Ferrous-Nickel Slag in Blast Cleaning," Waste Management \& Research on Behalf of International Solid Waste Association (ISWA), Vol. 20, No. 3, 2002, pp. 269-278.

[10] S. Bellermare, "Method for Blast Cleaning Using Ilmenite Tailing Particles," US Patent No.6848973, 1 February 2005.

[11] United State Geological Survey (USGS), 2006.

[12] M. S. Amin, "The Ilmenite Deposit of Abu Ghalqa, Egypt," Economic Geology and the Bulletin of Society of Economic Geologists, Vol. 49, No. 1, January 1954, pp. 77-87. doi:10.2113/gsecongeo.49.1.77

[13] E. M. El-Shazly, "Report on the Ilmenite Ore at Abu Ghalaga Eastern Desert," Unpublished Report, Geological Survey and Mineral Research Department, Cairo, 1959.

[14] E. Z. Basta and M. A. Takla, "Petrological Studies on Abu Ghalaga Ilmenite Occurrence, Eastern Desert," Journal of Geology, Vol. 12, No. 2, 1968, pp. 43-72.

[15] E. Z. Basta, "New Data on the System $\mathrm{Fe}_{2} \mathrm{O}_{3}$ $\mathrm{FeTiO}_{3}-\mathrm{TiO}_{2}$ (Ferri-Ilmenite and Titanomagetite) ," Proceeding Egyptian Academic Science, Cairo, Vol. 14, 1959, pp. 1-15.

[16] E. Z. Basta and M. A. Takla, "Mineralogy and Origin of Abu Ghalaga Ilmenite Occurrence, Eastern Desert," Journal of Geology, Vol. 12, No. 2, 1968, pp. 87-124.

[17] Ikonnicova, UIMS Institute, "Mineralogy and Chemical Composition of the Abu Ghalga Ilmenite Deposits: Geological Survey of Egypt (Unpublished report)," 1975.

[18] Technip Offshore UK Specification UK, 002444-TUKPL-SP-0012 Rev. B 15-01-204.
[19] ISO 8502-3, "Preparation of Steel Substrates before Application of Paints and Related Products-Tests for the Assessment of Surface Cleanliness Part 3: Assessment of Dust on Steel Surfaces Prepared for Painting (Pressure-Sensitive Tape Method)," 1992.

[20] American Society for Testing and Materials, "ASTM Method D 4417 Standard Test Methods for Field Measurement of Surface Profile of Blast Cleaned Steel," 2 June 2003.

[21] American Society for Testing and Materials, "ASTM Method: C 136 Standard Test Method for Materials Finer Than 75-MM (No. 200) Sieve in Mineral Aggregates by Washing," 2 April 1996.

[22] American Society for Testing and Materials, "ASTM Method: C 127, Standard Test Method for Density, Relative Density (Specific Gravity) and Absorption of Coarse Aggregate," 2 April 1993.

[23] American Society for Testing and Materials, "ASTM Method: C29/C29M, Standard Test Method for Bulk Density 'Unit Weight' and Voids in Aggregate," 2 April 1997.

[24] ISO 11127-6, "Preparation of Steel Substrates before Application of Paints and Related Products-Test Methods for Non-metallic Blast-Cleaning Abrasives-Part 6: Determination of Water-Soluble Contaminants by Conductivity Measurement," December1993.

[25] British Standard Institution, "BS 1377, Methods of Test for Soils for Civil Engineering Purposes. Classification tests PART2," 1990.

[26] American Society for Testing and Materials, "ASTM Method: D 4940, Standard Test Method for Conductimetric Analysis of Water Soluble Ionic Contamination of Blasting Abrasives," 2 June1994.

[27] Total Finaelaf, Exploration Production, "External Protection of off-Shore and Related Structures by Painting," General Specification Corrosion GS COR 350, Rev.1, 2004.

[28] AGIP Protective Coating and Hot Dip Galvanizing 2000. VAR.PAI. FUN. Specification, Rev. 2, September 1999.

[29] British Standard Institution "BS 2451, Specification for Chilled Iron Shot and Grit," July 1963. 